DOI: 10.34015/2523-4552.2021.2.02

УдК 343.2

\author{
Книженко О. О., \\ доктор юридичних наук, професор, \\ професор кафедри кримінального \\ права та кримінології Національної \\ академії служби безпеки України \\ ORCID: 0000-0001-9252-7464
}

\title{
НОВИЙ ПОГЛЯД НА ЗВІЛЬНЕННЯ ВІД ВІДБУВАННЯ ПОКАРАННЯ З ВИПРОБУВАННЯМ ЗА КОРУПЦІЙНІ КРИМІНАЛЬНІ ПРАВОПОРУШЕННЯ
}

\author{
«Науку часто плутають зі знанням. Це грубе \\ непорозуміння. Наука є не тільки знання, а й свідомість, \\ тобто вміння користуватися знанням як слід»
}

Василь Ключевський

У публікації по-новому оцінено питання укладення угоди у кримінальному провадженні про корупційні правопорушення з узгодженням звільнення від відбування покарання з випробуванням. Обгрунтовується доцільність застосування звільнення від відбування покарання з випробуванням за цей вид кримінального правопорушення. Авторка, відійшовши від своєї раніше висловленої позиції, наводить аргументи, спираючись на рішення Європейського суду з прав люди, чому варто застосовувати цей інститут у разі вчинення корупційних кримінальних правопорушень. Також ставиться під сумнів законодавчі положення щодо виключення застосування не тільки звільнення від відбування покарання з випробуванням за корупційні кримінальні правопорушення, а й низки інших норм, які нині неможливо використати за вчинене корупційне правопорушення.

Ключові слова: кримінальна відповідальність; звільнення від відбування покарання з випробуванням; корупція; корупційне правопорушення; корупційний злочин.

В публикации по-новому оценен вопрос заключения соглашения в уголовном производстве о коррупционных правонарушениях с согласованием освобождение от отбывания наказания с испытанием. Обосновывается целесообразность применения освобождения от отбывания наказания с испытанием за этот вид уголовного правонарушения. Автор, отойдя от своей ранее высказанной позиции, приводит аргументы, опираясь на решение Европейского суда по правам человека, в пользу применения этого института в случае совершения коррупционных уголовных правонарушений. Также ставятся под сомнение законодательные положения об исключении применения не только освобождение от отбывания наказания с испытанием за коррупционные преступления, но и других норм, которые сейчас невозможно использовать за совершенное коррупционное правонарушение.

(C) Книженко 0. 0., 2021

17 | С торінка 
Ключевые слова: уголовная ответственность; освобождение от отбывания наказания с испытанием; коррупция; коррупционное правонарушение; коррупционное преступление.

Постановка проблеми. Для нашої держави запобігання корупційним проявам й донині залишається вельми актуальним і вимагає від суспільства оцінити наявні проблеми в цій сфері 3 урахуванням запроваджених змін до чинного законодавства та практики його застосування. Не дивлячись на створені в Україні антикорупційні органи, прийняття низки законодавчих актів, якими передбачено більш суворі заходи кримінальноправового реагування за вчинені корупційні правопорушення, все ще залишається високий рівень корупції, зокрема політичної. Варто вказати, що це розуміють як державні діячі, так й аналітики, оскільки саме на цей чинник було вказано в аналітичній доповіді до щорічного Послання Президента України до Верховної Ради України «Про внутрішне та зовнішнє становище України» 2020 року як на одну з інституційних проблем Української держави [1].

Вітчизняна антикорупційна політика переважно здійснюється двома шляхами. Перший 3 них створення спеціалізованих державних органів, другий - встановлення більш суворих санкцій за корупційні правопорушення. Не зменшуючи значущості відзначених дій щодо запобігання корупційним проявам, свою увагу приділю критиці встановлених суворих кримінальноправових санкції.

Аналіз останніх досліджень і публікацій. Питанню звільнення від відбування покарання з випробуван- ням присвячено наукові праці А. В. Андрєєва, О. В. Беци, О. П. Гороха, О. М. Звенигородського, А. І. Золотарьова, А. О. Клевцова, Є. С. Назимка, $€$. О. Письменського, Д. В. Ягунова та iн.

У літературі докладно визначено місце звільнення від відбування покарання 3 випробуванням у системі засобів кримінально-правового реагування на вчинені кримінальні правопорушення, розглянуто проблеми визначення початку перебігу іспитового строку, обов'язків, які покладаються на засудженого, а також можливості призначення додаткових видів покарань під час звільнення з випробуванням.

Виділення не вирішених раніше частин загальної проблеми. Зміни, внесені до КК України від 14.10.2014 року $3 У$ «Про Національне антикорупційне бюро України», якими держава посилила заходи, спрямовані на протидію корупції, не всіма вченими, які вказані, розглядалися. Також висловлені ними позиції щодо зазначених змін $\epsilon$ діаметрально протилежними. При цьому обгрунтування думок обстоюється різними аргументами. Як наслідок маємо неоднакову судову практику.

Варто відзначити, що й авторка цієї публікації по-різному поставилась до цього питання. Зокрема, мною в 2015 році була висловлена позиція, від якої згодом відійшла. Причиною таких змін $є$ аналіз практики Європейського суду з прав людини.

Така ситуація склалася через те, що проблема звільнення особи 
від відбування покарання з випробуванням за корупційні правопорушення у випадку затвердження угоди про примирення або про визнання вини на теоретичному рівні $\epsilon$ слабко розробленою.

Постановка завдання. Метою цієї публікації є дослідження питання доцільності звільнення особи від відбування покарання з випробуванням при засудженні за корупційні правопорушення.

Виклад основного матеріалу. Згідно зі внесеними змінами до КК України, зокрема ч. 1 ст. 75 КК, нині застосування звільнення від відбування покарання з випробуванням у разі засудження за корупційні правопорушення $\epsilon$ неможливим. Цією нормою законодавець вказав на однозначність тлумачення, чого не скажеш про частину другу цієї норми. Так у ній зазначається, що суд приймає рішення про звільнення від відбування покарання з випробуванням у випадку затвердження угоди про примирення або про визнання вини, якщо сторонами угоди узгоджено покарання у виді виправних робіт, службового обмеження для військовослужбовців, обмеження волі, позбавлення волі на строк не більше п'яти років, а також узгоджено звільнення від відбування покарання 3 випробуванням. Такий виклад тексту зумовив появу дискусії щодо можливості звільнення від відбування покарання з випробуванням за корупційне правопорушення у разі укладення угоди.

Мною у раніше опублікованій праці обстоювалася думка, що в разі вчинення корупційного злочину узгодити можна тільки покарання, його вид та розмір, однак звільнення від відбування покарання з випробу- ванням - ні [2]. Обгрунтовувала це наступними основними доказами.

По-перше, передусім звертала увагу на положення ст.ст. 471, 472 КПК України. У них вказано, що зміст угоди про примирення або про визнання вини поміж істотних для відповідного кримінального провадження обставин та інших обов'язкових, передбачених у цих нормах, положень, має містити узгоджене покарання та згоду сторін на його призначення або на призначення покарання та звільнення від його відбування 3 випробуванням. Задля реалізації цих положень КПК України у 2012 році ЗУ «Про внесення змін до деяких законодавчих актів України у зв'язку з прийняттям Кримінального процесуального кодексу України» від 13.04.2012 року було доповнено ст.75 КК України частиною другою, яка забезпечувала б застосування звільнення від відбування покарання з випробуванням i під час укладення угод у кримінальному провадженні. Без внесення зазначених змін було б неможливим укладення угоди щодо звільнення від відбування покарання з випробуванням.

По-друге, укладаючи такі угоди, прокурор передусім керується положеннями Загальної, які не дозволяють застосування звільнення 3 випробуванням за корупційне кримінальне правопорушення.

По-третє, $\epsilon$ помилковим оцінювання як дві самостійні абсолютно незалежні норми, які містяться в ч. 1 та ч. 2 ст. 75 КК через те, що в ч. 1 визначено підстави та умови застосування звільнення від відбування покарання з випробуванням.

По-четверте, генезис інституту звільнення від відбування покаран- 
ня з випробуванням засвідчує, що, зародившись у другій половині XIX ст. як альтернатива короткочасному позбавленню волі та одержавши світового поширення, цей захід дозволив застосування мінімального кримінально-правового впливу до особи, яка викликала переконання в тому, що вона здатна виправитися без відбування призначеного покарання.

По-п'яте, самостійне тлумачення ч. 2 ст. 75 КК є неможливим через системність тлумачення закону про кримінальну відповідальність, оскільки потребувало б в такому разі самостійного тлумачення й положень ч. 5 ст. 65 КК, що дозволяло б укладати угоди, приміром, до 2-х місяців позбавлення волі. Однак, вочевидь, таке припущення спотворює принцип законності та створює можливість маніпулювання законом, що у свою чергу, є корупціоногенним фактором у правозастосовній практиці.

Не відмовляючись від раніше висловлених аргументів, хочу навести наступні положення, які засвідчать, що все вказане вище матиме другорядну роль, а тому вплине на правозастосування.

По-перше, вважаю, що використана законодавча техніка має чітко відображати сутність нормативних приписів, зміст яких особа не повинна вгадувати. 3 огляду на це не випадково на якість закону звертає увагу у своїх рішеннях Європейський суд 3 прав людини (ЄСПЛ). Нині, коли держава нерідко не в змозі захистити природні права людини й часто принцип законності тяжіє над верховенством права, особливої ваги набуває практика Європейського суду з прав людини. Його було утворено для за- безпечення дотримання зобов'язань, вчасного виконання рішень, прийнятих на себе державами-учасницями, які підписали та ратифікували Конвенцію про захист прав людини і основоположних свобод. Для України ця конвенція набрала чинності 11 вересня 1997 року. Однак тільки в 2006 році в нашій державі прийнято закон «Про виконання рішень та застосування практики Європейського суду з прав людини». Згідно цього закону рішення Європейського суду 3 прав людини $є$ не тільки обов'язковими для виконання Україною (ч. 1 ст. 2), а слугують й джерелом права (ст. 17), а ст. 19 говорить, що практика Європейського суду з прав людини також застосовується у сфері законодавства та в адміністративній практиці.

Зокрема ЄСПЛ визнає, що наслідки закону мають бути достатньо передбачуваними, а його формулювання повинно бути чітким, щоб надати змогу особі (а якщо потрібно з відповідною порадою) регулювати свою поведінку. Практика Європейського суду з прав людини свідчить про те, що не визнають особу винуватою у разі неякісного законодавства, коли неможливо через вади нормативних актів спрогнозувати наслідки їх застосування. Так, у справі «Вєренцов проти України” ввід 11 квітня 2013 року звертається увага на те, що «Будь-які обмеження, що накладаються, мають базуватися на положеннях основного законодавства. Саме законодавство повинно бути сформульованим 3 достатньою чіткістю, щоб надати особі можливість визначити, чи буде її поведінка суперечити закону, та якими можуть бути вірогідні наслідки порушень. Передбачення у національному законодавстві чітких визначень 
$\epsilon$ істотною умовою для того, щоб закон залишався нескладним для розуміння та застосування. Отже, визначення мають бути не надто деталізованими і не надто широким [3]».

Відзначається у рішеннях ЄСПЛ й на те, що поняття «право», використане в статті 7 Конвенції, відповідає поняттю «закон», яке фігурує в інших статтях Конвенції; охоплює національне право і має відповідати доступності й можливості передбачення наслідків (у справах «Кантоні проти Франції» [4] та «Ергін проти Туреччини» (Ergín v Turkey) [5]. Ці якісні вимоги повинні бути дотримані як щодо визначення правопорушення, так і покарання за нього (рішення у справі «Ашур проти Франції» 29 березня 2009) [6]. Особа повинна знати із тексту відповідного положення та, у разі необхідності, за допомогою його тлумачення судами, які дії та бездіяльність призводять до кримінальної відповідальності та яке покарання буде призначено за дію та/або бездіяльність, про яку йдеться (вищенаведене рішення у справі «Кантоні проти Франції»).

Аналіз тексту ст. 75 КК України засвідчує, що норму сформульовано таким чином, що особа не в змозі, навіть з допомогою фахівців, передбачити заходи можливого кримінально-правового реагування щодо неї у разі укладення угоди. Це свідчить про низьку якість законодавства. Тому у такому разі держава не повинна за рахунок потурання прав людини притягати особу до кримінальної відповідальності. Якісний закон - це обов'язок держави.

Судам, здійснюючи правосуддя, необхідно долати сумніви щодо тлумачення неякісного закону на ко- ристь особи, яку засуджують. Національні суди відповідальні за застосування європейського права. Саме від них у багатьох випадках вимагається його пряме застосування. На них також покладається і тлумачення національного права у відповідності 3 європейськими стандартами.

По-друге, закон не обмежує застосування звільнення від відбування покарання 3 випробуванням за вчинення тяжких та особливо тяжких злочинів, оскільки у ст. 75 КК України йдеться про призначене покарання, а не те, яке передбачено санкцією відповідної норми [7; с. 91]. Це означає, що через використання ст. 69 КК України можливо звільнити особу від відбування покарання 3 випробуванням й за тяжкі та особливо тяжкі злочини. Корупційні кримінальні правопорушення - це не тільки злочини, а й проступки також (приміром ст. 210 КК України). Норма, якою обмежено застосування звільнення 3 випробовуванням за корупційні кримінальні правопорушення, порушує принцип диференціації відповідальності. Варто відзначити, що порушують цей принцип й інші нововведенні норми у 2014 році про які йшлося на початку. Законодавцю необхідно переглянути ці положення та узгодити з принципами кримінального права.

По-третє, під час внесення змін до згаданого закону не додержано також і принцип справедливості. Так, маємо ситуацію за якої обмежено застосування цього інституту у разі посягання на благо, яке може бути поновлено, оскільки при вчиненні корупційних правопорушень права можна відновити повною мірою. Проте положення закону про кримінальну відповідальність дозволяють 
застосування звільнення з випробуванням у разі посягання на права, які не можуть бути поновлено (наприклад, життя при вбивстві).

По-четверте, проведені численні соціологічні дослідження підтверджують, що в Україні присутній високий індекс сприйняття корупції. Вважаю, що це $є$ одним із чинників, який породжує корупційні діяння. 3 огляду на вказане, доцільно вживати заходи, які спрямовані на зміну свідомості населення, а не на жорсткі заходи кримінально-правового реагування.

По-п'яте, особи, які вчиняють корупційні правопорушення, у порівнянні з тими, що вчиняють тяжкі та особливо тяжкі злочини, $є$ соціально адаптивні. Тому до них варто вживати менш суворі заходи реагування держави ніж за вчинення тяжких чи особливо тяжких злочинів.

Висновки. Укладаючи угоди у кримінальному провадженні про корупційні кримінальні правопорушення, $\epsilon$ не тільки доцільним, а й справедливим застосування звільнення від відбування покарання 3 випробуванням. Законодавцеві у подальшому варто переглянути заходи кримінально-правового реагування за корупційні діяння 3 тим, щоб мати обгрунтовані, справедливі та узгоджені кримінально-правові санкції.

\section{Список використаних джерел}

1. Аналітична доповідь до щорічного Послання Президента України до Верховної Ради України «Про внутрішнє та зовнішнє становище України». URL: https://niss.gov.ua/publikacii/poslannya-prezidenta-ukraini/analitichna-dopovid-doschorichnogo-poslannya-prezidenta-4 (дата звернення 16.07.2021).

2. Книженко 0. Звільнення від відбування покарання з випробуванням та укладення угод у кримінальному провадженні щодо корупційних злочинів. Вісник Луганського державного університету внутрішніх справ імені Е.О. Дідоренка. 2015. № 1 (69). C. $115-121$.

3. Рішення Європейського суду з прав людини від 11 квітня 2013 року у справі «Вєренцов проти України» URL: https://zakon.rada.gov.ua/laws/show/974_945\#Text (дата звернення 16.07.2021).

4. Рішення Європейського суду з прав людини від від 15 листопада 1996 року у справі «Кантоні проти Франції» URL: http://docs.pravo.ru/document/view/19382476/ (дата звернення 16.07.2021).

5. Рішення Європейського суду з прав людини від 6 травня 2006 року. у справі «Ергін проти Туреччини» (Ergín V Turkey». https://hudoc.echr.coe.int/fre\#\{\%22itemid\%22:[\%22001-75327\%22]\} (дата звернення 16.07.2021).

6. Рішення Європейського суду з прав людини від 29 березня 2009 у справі «Ашур проти Франції». URL: http://docs.pravo.ru/document/view/19382556/ (дата звернення 16.07.2021).

7. Книженко О. О. Звільнення від відбування покарання з випробуванням за кримінальним правом України: дис. ... канд. юрид. наук. Харків, 2003. 207 с.

\section{References}

Knizhenko, O. (2015). Zvilnennya vid vidbuvannya pokarannya $\mathrm{z}$ viprobuvannyam ta ukladennya ugod $\mathrm{u}$ kriminalnomu provadzhenni shodo 
korupcijnih zlochiniv. Visnik Luganskogo derzhavnogo universitetu vnutrishnih sprav imeni E. O. Didorenka, 1 (69), 115-121.

Knizhenko, O. O. (2003). Zvilnennya vid vidbuvannya pokarannya $Z$ viprobuvannyam za kriminalnim pravom Ukrayini: dis. ... kand. yurid. nauk. Harkiv.

O. Knyzhenko, Doctor Habil. of Law, Professor, Professor of the Chair of Criminal Law and Criminology, National Academy of Security Service of Ukraine

ORCID: 0000-0001-9252-7464

\section{A Fresh Look at the Release from Punishment for Corruption Crimes on Probation}

This publication assesses from the new perspective such an issue as entering into an agreement in criminal proceedings on corruption crimes which arranges a release from serving the punishment on probation. The author shows that release from punishment on probation in case of such criminal offenses is justified. Having moved away from the position she expressed previously, based on the judgments of the European Court of Human Rights, the author gives arguments why this institution should be applied in case corruption crimes are committed. She also challenges the legislative provisions which exclude not only a release from serving the punishment for corruption crimes on probation, but also a range of other rules which may not be currently used for a committed corruption crime.

When concluding agreements in criminal proceedings on corruption offenses, it is not only expedient but also fair to apply exemption from probation. The legislator should further review the measures of criminal law response to corruption in order to have reasonable, fair and consistent criminal sanctions.

Keywords: criminal liability; release from serving a probation sentence; corruption, corruption offense; corruption crime. 